\title{
FAKTOR-FAKTOR YANG MEMPENGARUHI TOKSISITAS BAHAN PENCEMAR TERHADAP ORGANISME PERAIRAN
}

\author{
Oleh \\ Triyoni Purbonegoro')
}

\begin{abstract}
FACTORS THAT AFFECTING THE TOXICITY OF POLLUTANTS TO AQUATIC ORGANISMS. There are a large number of pollutants in aquatic environment with various characteristics and factors that can modify and affect the toxicity of pollutants in this environment. The major factors affecting pollutant toxicity include physicochemical properties of pollutants, mode of exposure, time, environmental factors, and biological factors. Moreover, organisms in an aquatic ecosystem are seldom exposed to only single pollutant, and most cases the stress of pollution on aquatic ecosystems is related to the interaction and combined effects of many chemicals. The combined effects may be synergistic or antagonistic, depending on the pollutants and the physiological condition of the organism involved.
\end{abstract}

\section{PENDAHULUAN}

Ribuan jenis bahan pencemar terlepas ke lingkungan laut akibat aktivitas manusia (Blasco et al., 2016). Karakteristik air dan organisme dapat mempengaruhi toksisitas bahan pencemar tersebut (Rand \& Petrocelli, 1985). Faktor-faktor yang mempengaruhi toksisitas tersebut terdiri dari faktor yang berhubungan dengan bahan pencemar (fisika-kimia) dan faktor yang berhubungan dengan organisme (biotik). Faktor fisika-kimia bahan pencemar meliputi konsentrasi, suhu, $\mathrm{pH}$, salinitas, dan kesadahan. Faktor biotik meliputi spesies, umur, dan kondisi kesehatan organisme (Rand \& Petrocelli, 1985).

Faktor lain yang dapat mempengaruhi toksisitas yaitu interaksi antar bahan pencemar (Landis \& Yu 2004). Hal tersebut dilatar belakangi oleh fenomena bahwa organisme perairan jarang terpapar oleh satu jenis bahan pencemar saja melainkan bermacam bahan pencemar yang saling berinteraksi (Okamura \& Aoyama 1994). Secara umum interaksi bahan pencemar dapat bersifat sinergis maupun antagonis, tergantung pada karakter fisika-kimia bahan pencemar dan kondisi fisiologis organisme yang terpapar (Landis \& Yu, 2004).

Pengetahuan mengenai faktorfaktor tersebut berguna antara lain dalam upaya untuk pemantauan dan pengendalian pencemaran di lingkungan pesisir dan lautan. Tulisan ini bertujuan untuk memberikan informasi singkat mengenai

\footnotetext{
${ }^{1)}$ Kelompok Penelitian Pencemaran Laut dan Bioremediasi, Pusat Penelitian Oseanografi-LIPI
} 
faktor-faktor yang mempengaruhi toksisitas bahan pencemar terhadap organisme perairan secara umum.

\section{FAKTOR FISIKA-KIMIA BAHAN PENCEMAR KONSENTRASI BAHAN PENCEMAR}

Menurut Landis \& Yu (2004), konsentrasi bahan pencemar merupakan faktor penting yang mempengaruhi toksisitas. Bahan pencemar dengan toksisitas tinggi tidak akan terlalu memberi dampak terhadap organisme, apabila masih dalam konsentrasi sangat rendah. Sebaliknya bahan pencemar dengan toksisitas rendah, akan berpengaruh buruk apabila dipaparkan dengan konsentrasi tinggi. Faktor penting lain yang mempengaruhi toksisitas adalah lamanya pemaparan (durasi) bahan kimia terhadap organisme. Pemaparan yang lebih lama akan memberi dampak kronis yang lebih buruk terhadap organsime perairan (Rand \& Petrocelli, 1985; Landis \& Yu, 2004).

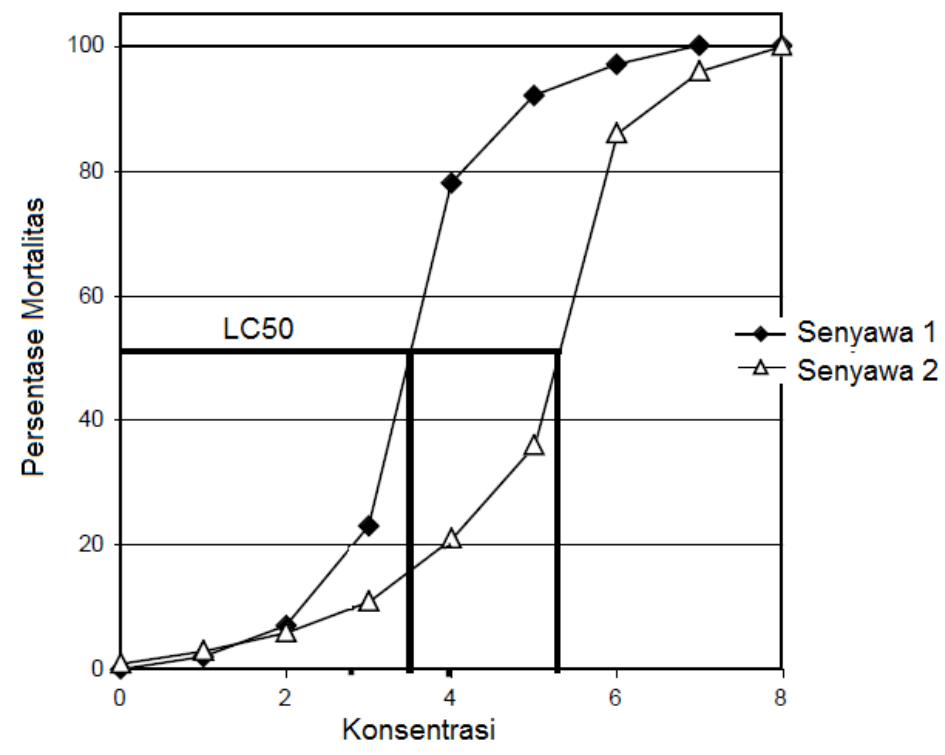

Gambar 1. Kurva konsentrasi-respon dua senyawa kimia yang berbeda (modifikasi dari Landis \& Yu, 2004).

Ilustrasi hubungan antara konsentrasi bahan kimia dan respon yang ditimbulkan pada organisme dalam jangka waktu tertentu dapat dilihat pada Gambar 1. Hubungan konsentrasi-respon tersebut tidak bersifat linear, namun sigmoid. Secara umum, pada batas tertentu semakin besar konsentrasi bahan kimia, maka respon yang ditimbulkan akan lebih buruk (Rand
\& Petrocelli, 1985). Dua jenis bahan kimia yang berbeda, dapat menimbulkan respon yang berbeda pada organisme yang sama (Landis \& Yu, 2004). Pada Gambar 1, terlihat bahwa $\mathrm{LC}_{50}$ senyawa 1 lebih kecil dibandingkan senyawa 2 . Hal ini menunjukkan bahwa senyawa 1 bersifat lebih toksik dibandingkan senyawa 2. 


\section{SUHU/TEMPERATUR}

Beberapa penelitian melaporkan bahwa bioakumulasi dan toksisitas bahan pencemar meningkat seiring dengan perubahan suhu (Heugens et al., 2003; Sokolova \& Lannig, 2008; Zhou et al., 2014; Baines et al., 2006). Peningkatan suhu diketahui dapat menurunkan kandungan oksigen terlarut di perairan (Landis \& Wu, 2004). Lewis et al. (2016) melaporkan bahwa toksisitas tembaga (Cu) terhadap isopoda Exosphaeroma gigas meningkat seiring dengan kenaikan suhu sebesar $10^{\circ} \mathrm{C}$ (Tabel 1). Toksisitas $\mathrm{Cu}$ meningkat (ditandai dengan semakin kecilnya nilai $\mathrm{LC}_{50}$ ) hingga $>44 \%$ dari $2204 \mu \mathrm{g} . \mathrm{L}^{-1}$ pada suhu $5,5^{\circ} \mathrm{C}$ menjadi $1245 \mu \mathrm{g} . \mathrm{L}^{-1}$ pada suhu $15^{\circ} \mathrm{C}$. Sementara itu, waktu yang dibutuhkan untuk menyebabkan kematian $\left(\mathrm{LC}_{\mathrm{T} 50}\right)$ pada konsentrasi $\mathrm{Cu} 2200 \mu \mathrm{g} . \mathrm{L}^{-1}$ menjadi dua kali lebih cepat. Dengan demikian, toksisitas suatu bahan pencemar akan meningkat seiring kenaikan suhu ditunjukkan dengan menurunnya nilai $\mathrm{LC}_{50}$ dan $\mathrm{LC}_{\mathrm{T} 50}$.

Tabel 1. Pengaruh suhu terhadap toksisitas $\mathrm{Cu}$ pada isopoda Exosphaeroma gigas selama 14 hari uji (Lewis et al., 2016).

\begin{tabular}{|c|c|c|}
\hline $\begin{array}{c}\text { Perlakuan Suhu } \\
\left({ }^{\circ} \mathrm{C}\right)\end{array}$ & $\begin{array}{c}\mathrm{LC}_{50} 14 \text { hari } \\
\left(\mu \mathrm{g} . \mathrm{L}^{-1}\right)\end{array}$ & $\mathrm{LC}_{\mathrm{T} 50}$ pada $2200 \mu \mathrm{g} . \mathrm{L}^{-1}$ (hari) \\
\hline 5,5 & 2204 & 12,5 \\
\hline 10 & 2077 & 10,7 \\
\hline 15 & 1245 & 6,3 \\
\hline
\end{tabular}

Peningkatan bioakumulasi dan toksisitas bahan pencemar berkaitan dengan peningkatan aktivitas dan kinetik logam, serta peningkatan laju metabolisme di perairan yang lebih hangat (Robertson et al., 2001). Perubahan suhu juga mempengaruhi proses sintesis protein, respirasi dan transpor energi, serta kemampuan menghantarkan oksigen (Pörtner, 2001). Perubahan laju metabolisme dapat menyebabkan perubahan perilaku, misalnya pergerakan dan aktivitas makan yang mempengaruhi kemampuan mengakumulasi bahan pencemar (Sokolova \& Lannig, 2008; Lewis et al., 2016). Peningkatan penyerapan bahan pencemar menyebabkan peningkatan akumulasi
(Heugens et al., 2003; Mubiana \& Blust, 2007; Sokolova \& Lannig, 2008). Tekanan/stress akibat perubahan suhu juga dapat mengganggu kemampuan detoksifikasi bahan pencemar (Lannig et al., 2006). Hal ini berpotensi meningkatkan toksisitas (Lewis et al., 2016).

\section{KADAR KEASAMAN (pH)}

Penurunan $\mathrm{pH}$ di lingkungan perairan antara lain disebabkan oleh pengasaman (asidifikasi). Asidifikasi merupakan salah satu penyebab utama degradasi lingkungan, tidak hanya disebabkan oleh toksisitasnya, namun juga karena efeknya terhadap spesiasi, mobilitas, dan bioavailabilitas bahan kimia (Stumm \& Morgan, 
1996). Untuk sebagian organisme perairan, $\mathrm{pH}$ rendah dapat meningkatkan toksisitas logam (Pynnönen, 1995). Adanya hubungan yang kuat antara penurunan $\mathrm{pH}$ dan peningkatan kelarutan ion logam dapat menyebabkan peningkatan bioakumulasi dan toksisitas (Campbell, 1995). Meski demikian, hubungan antara $\mathrm{pH}$ dan toksisitas logam sebenarnya jauh lebih rumit, tergantung pada ikatan kimia dan spesies logam (Sandifer \& Hopkin, 1996). Henriksen et al. (1984) melaporkan bahwa toksisitas alumunium (Al) terhadap ikan salmon Salmo gairdneri meningkat pada $\mathrm{pH}$ rendah. Kondisi tersebut dijelaskan oleh Dietrich \& Schlatter (1989) bahwa gangguan fisiologi yang terjadi pada $\mathrm{pH}$ rendah $(5,4)$ meliputi hilangnya elektrolit, kerusakan sel, kerusakan pada insang yang menyebabkan gangguan proses pernafasan.

\section{SALINITAS}

Salinitas berpengaruh pada toksisitas bermacam bahan pencemar, terutama logam terhadap organisme estuari dan laut (Grosell et al., 2007; Hall \& Anderson, 1995). Pada beberapa penelitian, toksisitas logam menurun seiring dengan peningkatan salinitas, dimana kejadian sebaliknya juga teramati dan merupakan hal yang rumit (Grosell et al., 2007; Hall \& Anderson, 1995). Salinitas tidak hanya mempengaruhi geokimia logam, tapi juga pada fisiologi organisme dan sensitivitasnya terhadap pemaparan logam (Grosell et al., 2007; Jones et al., 1976; Pinho \& Bianchini, 2010).
Hewan yang hidup di daerah estuari memiliki strategi yang berbeda untuk merespon variasi salinitas di lingkungan mereka. Hewan osmoregulator mampu dan secara aktif mengatur konsentrasi garam dalam cairan tubuhnya, serta menjaga agar tetap dalam kondisi stabil. Hewan lainnya yang tidak mampu menyesuaikan hal tersebut, akan tetap berupaya menjaga kondisi cairan dalam tubuhnya (isoosmotik) berbeda dengan lingkungan sekitarnya (Chen et al., 2017). Pemaparan zink $(\mathrm{Zn})$ terhadap kepiting pantai Carcinus maenas pada salinitas rendah (20 ppt) menyebabkan peningkatan penyerapan $\mathrm{Zn}$ yang mengarah pada gangguan keseimbangan $\mathrm{Zn}$ dan $\mathrm{Ca}$ pada proses osmoregulasi dalam tubuh hewan tersebut (Chen et al., 2017).

\section{KESADAHAN}

Kesadahan (hardness) memiliki beberapa kesamaan dengan alkalinitas, biasa diekspresikan sebagai konsentrasi kalsium karbonat $\left(\mathrm{CaCO}_{3}\right)$, meskipun kesadahan merupakan konsentrasi kation $\left(\mathrm{Ca}^{2+}\right.$ dan $\left.\mathrm{Mg}^{2+}\right)$, sedangkan alkalinitas merupakan konsentrasi anion $\left(\mathrm{HCO}_{3}{ }^{-}\right.$dan $\mathrm{CO}_{3}{ }^{2-}$ ) (Weiner, 2000). Kesadahan berpengaruh terhadap toksisitas logam. Toksisitas logam akan menurun pada kondisi perairan dengan kesadahan tinggi (Rand \& Petrocelli, 1985). Markich (2013) melaporkan bahwa peningkatan kesadahan sebesar 20 kali lipat menyebabkan toksisitas uranium (U) makrofita Ceratophyllum demersum berupa inhibisi pertumbuhan menurun, hingga empat kali. 


\section{FAKTOR BIOTIK}

Menurut Rand \& Petrocelli (1985), setiap spesies memiliki sensitivitas yang berbeda terhadap bahan kimia. Hal ini disebabkan oleh perbedaan kemampuan dalam merespon bahan kimia tersebut. Beberapa spesies mampu melindungi dirinya sendiri dari paparan bahan pencemar untuk waktu yang singkat, misalnya kerang-kerangan mampu menutup cangkangnya dan tetap bermetabolisme dalam kondisi anaerob selama beberapa waktu. Wang et al. (2010) menjelaskan, bahwa invertebrata dan ikan laut memiliki kisaran sensitivitas yang berbeda terhadap kadmium $(\mathrm{Cd})$ (Gambar 2). Toksisitas $\mathrm{Cd}\left(\mathrm{LC}_{50}\right)$ terhadap
61 genus invertebrata dan ikan laut bervariasi hingga $10^{5}$ kali lipat, yakni berkisar antara 41,29 $\mu \mathrm{g} . \mathrm{L}^{-1}$ untuk krustasea kecil, Americamysis bahia hingga 135 mg.L - $^{-1}$ untuk cacing, Monopylephorus cuticulatus. Mysid, lebih sensitif 3270 kali lipat dibandingkan cacing oligochaete. $\mathrm{LC}_{50} \mathrm{Cd}$ untuk polychaeta berkisar antara $200 \mathrm{ug} / \mathrm{L}$, Capitella capitata hingga $135000 \mu \mathrm{g} . \mathrm{L}^{-1}$ untuk Monopylephorus cuticulatus. $\mathrm{LC}_{50}$ moluska berkisar antara $228 \mu \mathrm{g} . \mathrm{L}^{-1}$, Pasific oyster, Crassostrea gigas hingga $19170 \mu \mathrm{g} . \mathrm{L}^{-1}$, siput lumpur, Nassarius obsoletus. $\mathrm{LC}_{50}, 12$ spesies ikan berkisar antara $75 \mu \mathrm{g} . \mathrm{L}^{-1}$, ikan kakap, Morone saxatilis hingga $50 \mathrm{mg} . \mathrm{L}^{-1}$, dan untuk sheephead minnow, Cyprinodon variegates.

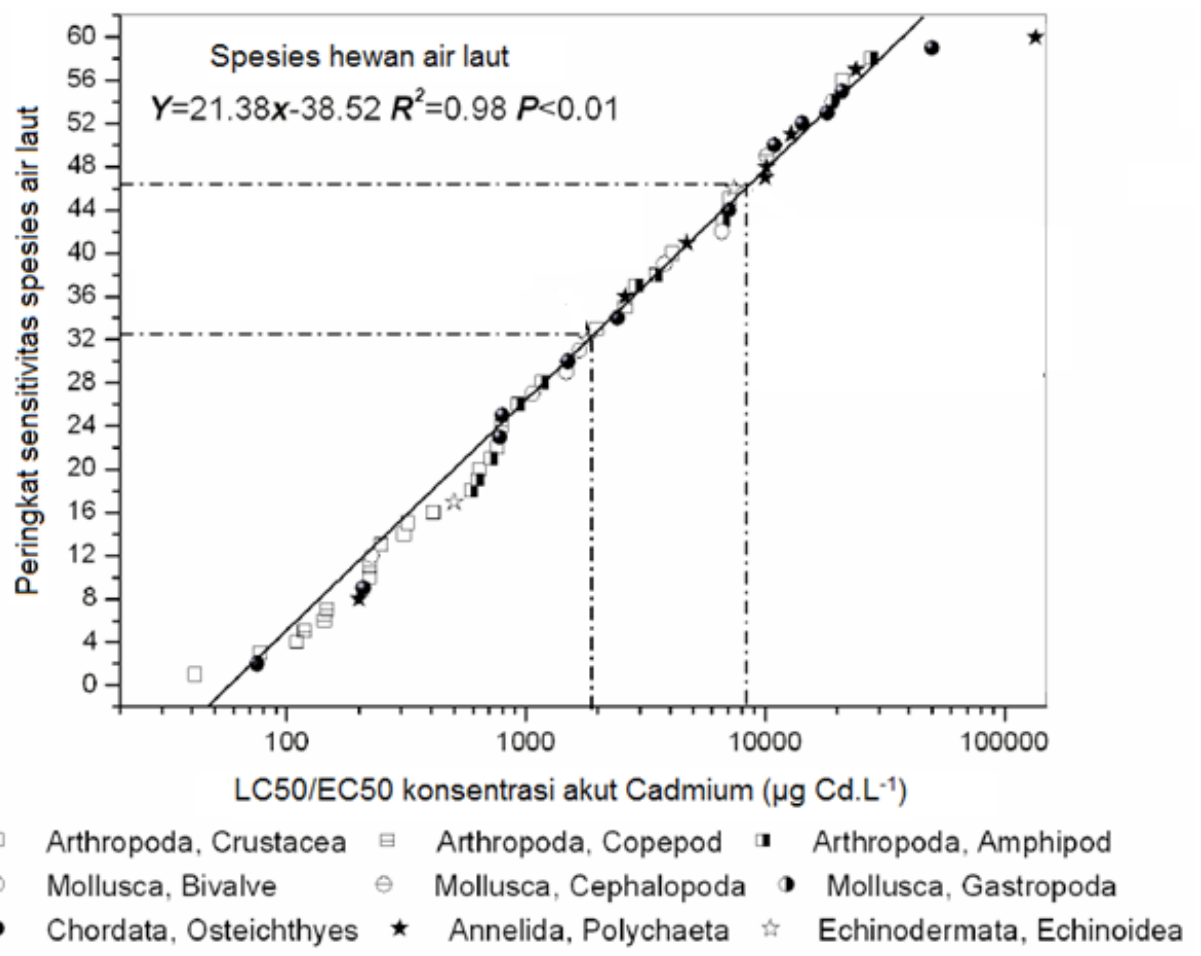

Gambar 2. Peringkat sensitivitas beberapa jenis organisme perairan laut terhadap kadmium (Cd) (modifikasi dari Wang et al., 2010). 
Menurut Rand \& Petrocelli (1985), organisme yang masih muda pada umumnya lebih rentan dan sensitif terhadap bahan pencemar dibandingkan organisme dewasa, hal ini disebabkan oleh perbedaan tingkat perkembangan mekanisme detoksifikasi antara organisme muda dan dewasa. Perbedaan dalam laju ekskresi juga berpengaruh terhadap kemampuan merespon dan mengeluarkan bahan pencemar. Untuk jenis Artropoda (krustasea) tahapan yang paling sensitif adalah pada saat molting (berganti cangkang) dan pada ikan adalah tahapan embrio-larva, serta juvenil awal. Pola makan organisme perairan dapat mempengaruhi efek toksisitas dengan cara menghasilkan perubahan pada komposisi tubuh, fungsi fisiologi dan biokimia, serta kondisi nutrisi organisme tersebut (Rand \& Petrocelli 1985).

\section{INTERAKSI BAHAN PENCEMAR}

Biota laut lebih sering terpapar
pada bermacam bahan pencemar
dibandingkan hanya pada satu jenis
bahan pencemar. Hampir pada setiap
kasus pencemaran lingkungan perairan
umumnya selalu berkaitan dengan efek
interaktif lebih dari satu jenis bahan
pencemar (Okamura \& Aoyama, 1994).
Secara umum, efek interaktif bahan
pencemar dapat berupa efek sinergis
atau antagonis (berlawanan), bergantung
pada jenis bahan pencemar dan kondisi

organisme yang terpapar. Efek sinergis merupakan efek toksisitas gabungan dua atau lebih bahan pencemar, dimana pengaruh toksisitas akan lebih besar dibandingkan hanya satu jenis bahan pencemar. Sebaliknya, efek antagonis terjadi pada kondisi dimana pengaruh toksisitas dua atau lebih bahan pencemar, akan lebih rendah dibandingkan efek yang terjadi pada pemaparan satu jenis bahan pencemar (Landis \& Yu, 2004).

Kajian terhadap efek sinergis bahan pencemar antara lain dilakukan oleh Clemow \& Wilkie (2015) yang meneliti pengaruh kadmium (Cd) dan timbal $(\mathrm{Pb})$ terhadap kemampuan bertahan hidup (survival) ikan trout pelangi, Onchorhyncus mykiss. Pada Gambar 3 disajikan grafik persentase kemampuan bertahan hidup ikan O. mykiss yang dipelihara dalam larutan kontrol, larutan $\mathrm{Cd}$ dan $\mathrm{Pb}$ yang dipaparkan terpisah, serta larutan berisi campuran $\mathrm{Cd}$ dan $\mathrm{Pb}$ dengan konsentrasi tertentu selama 120 jam. Seluruh ikan pada larutan kontrol mampu tetap bertahan hidup hingga akhir pengujian, sedangkan persentase ikan pada larutan uji $\mathrm{Cd}$ dan $\mathrm{Pb}$ yang dipaparkan sendiri-sendiri, masing-masing hanya $48 \%$ dan $85 \%$ yang mampu bertahan hidup. Sementara itu campuran $\mathrm{Cd}$ dan $\mathrm{Pb}$ menunjukkan efek sinergis yang lebih besar dibandingkan efek dari hanya satu jenis logam saja. Efek ini menyebabkan persentase bertahan hidup ikan menurun drastis hingga $16 \%$, selama 120 jam pemaparan. 


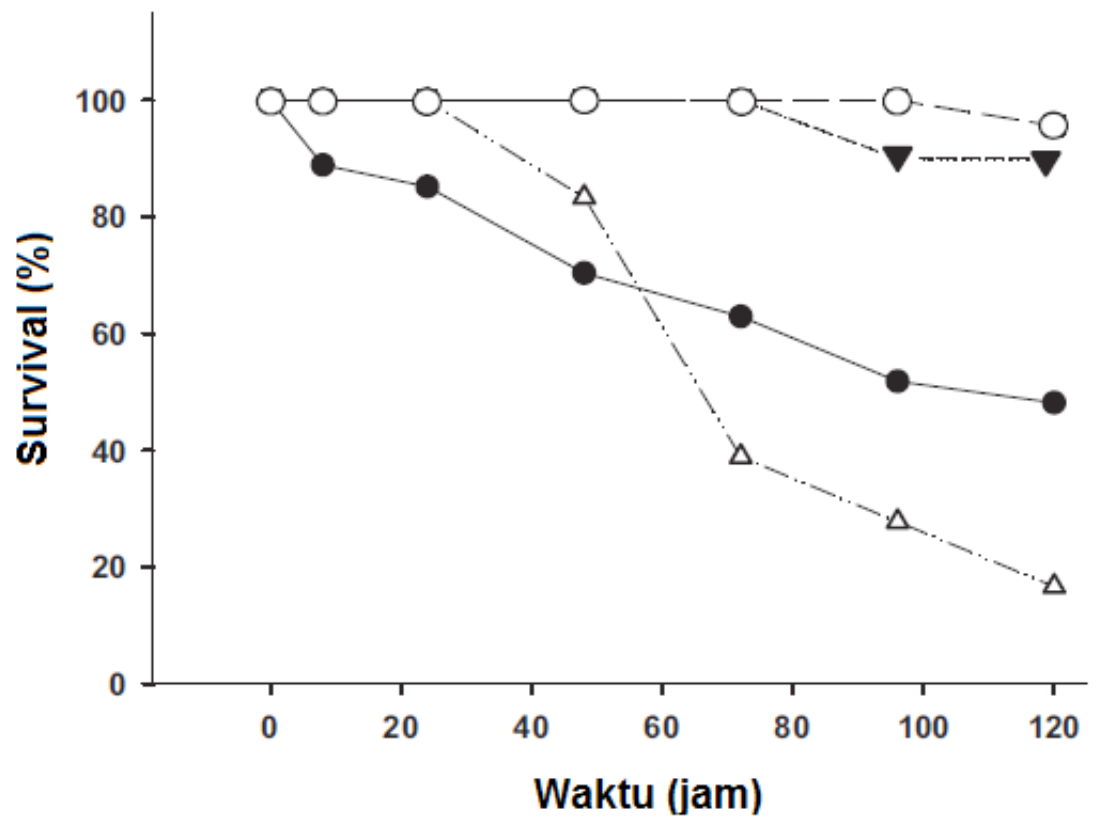

Gambar 3. Persentase bertahan hidup (survival) 1kan trout pelang1 (U. mykiss) pada pemaparan kontrol (०), 7,4 $\pm 0,3 \mathrm{nmol} \mathrm{L}{ }^{-1} \mathrm{Cd}(\bullet), 26,1 \pm 1,6 \mathrm{nmol} \mathrm{L}^{-1} \mathrm{~Pb}(\boldsymbol{\nabla})$,

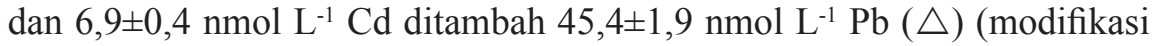
dari Clemow \& Wilkie, 2015).

Efek sinergis yang dihasilkan oleh bahan pencemar bergantung pada banyak faktor, antara lain sifat bahan kimia tersebut dalam prosesnya memasuki tubuh organisme dan kondisi fisiologis dan metabolisme organisme yang terpapar (Landis \& Yu, 2004). Logam berat Cd dan $\mathrm{Pb}$ yang terserap berpengaruh terhadap proses metabolisme tubuh ikan, karena berikatan dengan komponen seluler yang penting, seperti struktur protein, enzim, serta asam nukleat. $\mathrm{Cd}$ dan $\mathrm{Pb}$ memiliki sifat hampir sama dengan $\mathrm{Ca}^{2+}$ yang dibutuhkan pada proses respirasi mitokondria dan fungsi syaraf. Pada tubuh ikan penyerapan ion $\mathrm{Ca}^{2+}$ terjadi pada bagian insang (Clemow \& Wilkie, 2015). Penyerapan ion $\mathrm{Cd}$ dan $\mathrm{Pb}$ menggantikan ion $\mathrm{Ca}^{2+}$ menyebabkan terganggu- nya proses-proses penting tersebut. $\mathrm{Pb}$ juga dikenal menyebabkan terganggunya pembentukan sel darah merah dengan cara menghambat kerja enzim aminolevulinic acid dehydratase dan ferrochelatase, sedangkan $\mathrm{Cd}$ mengganggu sintesis ATP untuk menghasilkan energi (Landis \& Yu, 2004).

Kajian mengenai efek antagonis bahan pencemar antara lain dilakukan oleh Liu et al. (2013) yang meneliti pengaruh beberapa jenis pestisida terhadap alga hijau, Chlorella pyrenoidosa. Pestisida yang diujikan adalah Simetryn (herbisida), Bromacil (herbisida), Hexazinone (herbisida), Dodine (fungisida), dan Propoxur (insektisida). Efek dari masing-masing jenis pestisida yang dipa- 
parkan terpisah (tunggal) dan kombinasi dapat dilihat pada Tabel 2. Kombinasi beberapa jenis pestisida menunjukkan efek antagonis terhadap pertumbuhan C. pyrenoidosa. Sebagai contoh, kombinasi pestisida SIM-BRO-HEX-DOD-PRO menunjukkan nilai toksisitas $\left(p \mathrm{EC}_{50}\right)$ yang lebih kecil (2,93 $\left.\mathrm{mol} \mathrm{L}^{-1}\right)$ dibandingkan nilai toksisitas pestisida Simetryn ketika dipaparkan secara terpisah $\left(5,6 \mathrm{~mol} \mathrm{~L}^{-1}\right)$. Hal ini menandakan bahwa C. pyrenoidosa lebih sensitif terhadap paparan Simetryn dan berbalik menjadi resisten/tahan, ketika dipaparkan pada beberapa jenis pestisida. Hal yang sama terjadi pada kombinasi beberapa jenis pestisida lainnya. Hal ini disebabkan karena satu atau lebih jenis pestisida mengurangi toksisitas jenis pestisida yang lain. Mekanisme tersebut masih belum jelas, hal tersebut disebabkan karena kurangnya data yang berkaitan dengan aktivitas molekuler pada alga tersebut, dan masih membutuhkan penelitian lebih lanjut.

Tabel 2. Efek beberapa jenis pestisida terhadap alga hijau (Chlorella pyrenoidosa) (Liu et al. 2013).

\begin{tabular}{|c|c|c|c|}
\hline $\begin{array}{c}\text { Pestisida } \\
\text { tunggal }\end{array}$ & $\begin{array}{c}\mathbf{p E C}_{\mathbf{5 0}} \text { tunggal } \\
\left(\mathbf{m o l ~ L}^{-1}\right)\end{array}$ & $\begin{array}{c}\text { Kombinasi } \\
\text { pestisida }\end{array}$ & $\begin{array}{c}\mathbf{p E C}_{\mathbf{5 0}} \text { kombinasi } \\
\left(\mathbf{m o l ~ L}^{-1}\right)\end{array}$ \\
\hline Simetryn (SIM) & 5,46 & SIM-BRO-HEX-DOD-PRO & 2,93 \\
Bromacil (BRO) & 4,77 & SIM-BRO-HEX & 2,84 \\
Hexazinone (HEX) & 5,44 & HEX-DOD & 2,90 \\
Dodine (DOD) & 5,26 & BRO-DOD & 3,47 \\
Propoxur (PRO) & 2,66 & & \\
\hline
\end{tabular}

Keterangan : $p \mathrm{EC}_{50}=-\log \mathrm{EC}_{50}$. Semakin besar nilai $p \mathrm{EC}_{50}$ maka semakin sensitif organisme terhadap suatu bahan kimia.

\section{PENUTUP}

Beragam jenis bahan pencemar yang masuk ke lingkungan perairan akibat peningkatan aktivitas antropogenik, akan menimbulkan dampak buruk terhadap organisme perairan. Beberapa penelitian menunjukkan bahwa toksisitas bahan pencemar terhadap organisme perairan dipengaruhi bermacam faktor kompleks yang merupakan keterkaitan antara karakter lingkungan perairan, kondisi organisme, dan interaksi antar bahan pencemar. Pemahaman terhadap keterkaitan faktor-faktor tersebut sangat penting untuk menduga dampak yang ditimbulkan dan menentukan upaya yang dapat ditempuh untuk menguranginya.

\section{DAFTAR PUSTAKA}

Baines, S.B., N.S. Fisher and E.L. Kinney. 2006. Effects of temperature on uptake of aqueous metals by blue mussels Mytilus edulis from Arctic and temperate waters. Mar. Ecol. Prog. Ser. 308, 117-128. 
Blasco, J., P.M. Chapman, O. Campana and M. Hampel, 2016. Marine Ecotoxicology : Current Knowledge and Future Issues. Blasco et al. (eds). Academic Press. London. pp. 321.

Chen, W., W. Wang and Q. Tan. 2017. Revealing the complex effects of salinity on copper toxicity in an estuarine clam Potamocorbula laevis with a toxicokinetic-toxicodynamic model. Environmental Pollution. 222: 323-330.

Clemow, Y.H. and P. M. Wilkie. 2015. Effects of $\mathrm{Pb}$ plus $\mathrm{Cd}$ mixtures on toxicity, and internal electrolyte and osmotic balance in the rainbow trout (Oncorhynchus mykiss). Aquatic Toxicology. 161 : 176-188.

Dietrich, D. and C. Schlatter. 1989. Aluminium toxicity to rainbow trout at low $\mathrm{pH}$. Aquat. Toxicol.15:197-212.

Grosell, M., J. Blanchard, K.V. Brix and R. Gerdes 2007. Physiology is pivotal for interactions between salinity and acute copper toxicity to fish and invertebrates. Aquat. Toxicol. 84: 162-172.

Hall, L.W. and R.D. Anderson. 1995. The influence of salinity on the toxicity of various classes of chemicals to aquatic biota. Crit. Rev. Toxicol. 25:281-346.
Heugens, E.H.W., T. Jager, R. Creyghton, M.H.S. Kraak, A.J. Hendriks, N.M. Van Straalen and W. Admiraal. 2003. Temperature-dependent effects of cadmium on Daphnia magna: Accumulation versus sensitivity. Environ. Sci. Technol. 37:2145-2151.

Jones, L.H., N.V. Jones and A.J. Radlett. 1976. Some effects of salinity on the toxicity of copper to the polychaete Nereis diversicolor. Estuar. Coast. Mar. Sci. 4: 107-111

Lannig, G., J.F. Flores and I.M. Sokolova. 2006. Temperature-dependent stress response in oysters, Crassostrea virginica: pollution reduces temperature tolerance in oysters. Aquat. Toxicol. 79: 278-287.

Lewis, A., C.K. King, N.A. Hill, Ashley Cooper, A.T. Townsend and J.A. Mondon. 2016. Seawater temperature effect on metal accumulation and toxicity in the sub antarctic Macquarie Island isopod, Exosphaeroma gigas. Aquatic Toxicology. 177 : 333-342.

Liu, S., C. Wang, J. Zhang, X. Zhu and W. Li. 2013. Combined toxicity of pesticide mixtures on green algae and photobacteria. Ecotoxicology and Environmental Safety. 95:98-103. 
Mubiana, V.K. and R. Blust. 2007. Effects of temperature on scope for growth and accumulation of $\mathrm{Cd}, \mathrm{Co}, \mathrm{Cu}$ and $\mathrm{Pb}$ by the marine bivalve Mytilus edulis. Mar. Environ. Res. 63: 219-235.

Okamura, H., and I. Aoyama, 1994. Interactive Toxic Effect and Distribution of Heavy Metals in Phytoplankton. Environmental Toxicology and Water Quality. 9:7-15.

Pinho, G.L.L. and A. Bianchini. 2010. Acute copper toxicity in the euryhaline copepod Acartia tonsa: implications for the development of an estuarine and marine biotic ligand model. Environ. Toxicol. Chem. 29: 1834-1840

Pörtner, H. 2001. Climate change and temperature-dependent biogeography: oxygen limitation of thermal tolerance in animals. Naturwissenschaften. 88:137-146.

Pynnönen, K.1995. Effect of pH, hardness and maternal pre-exposure on the toxicity of $\mathrm{Cd}, \mathrm{Cu}$ and $\mathrm{Zn}$ to the glochidial larvae of a freshwater clam Anodontacygnea. Water Res. 29: 247-254.

Robertson, R., A. El-Haj, A. Clarke, L. Peck and E. Taylor. 2001. The effects of temperature on metabolic rate and protein synthesis following a meal in the isopod Glyptonotus antarcticus Eights (1852). Polar Biol. 24: 677-686.

Sandifer, R.D., and S.P. Hopkin. 1996. Effects of $\mathrm{pH}$ on the toxicity of cadmium, copper, lead and zinc to Folsomiacandida Willem, 1902 (Collembola) in a standard laboratory test system. Chemosphere. 33: 2475-2486.

Sokolova, I.M. and G. Lannig. 2008. Interactive effects of metal pollution and temperature on metabolism in aquatic ectotherms: implications of global climate change. Clim. Res. 37: 181-191.

Stumm,W. J.J. and Morgan, 1996. Aquatic Chemistry: Chemical Equilibria and Rates in Natural Waters, $3^{\text {rd }}$ eds. John Wiley \& Sons, Inc., New York, USA. 1022pp.

Wang, Z., C. Yan, H. Kong and D. Wu. 2010. Mechanisms of cadmium toxicity to various trophic saltwater organisms. Wang et al. (eds). Nova Science Publisher, Inc. New York.p. 84.

Weiner, E. R. 2000. Applications of environmental chemistry : a practical guide for environmental professionals. CRC Press. Boca Raton, Florida. 271 pp. 
Zhou, G.J., Z. Wang, E.T.C. Lau, X.-

R. Xu. and K.M.Y. Leung. 2014. Can we predict temperature-dependent chemical toxicity to marine organisms and set appropriate water quality guidelines for protecting marine ecosystems under different thermal scenarios? Mar. Pollut. Bull. 87: 11-21. 